\begin{tabular}{ccc} 
Coğrafi Bilimler Dergisi & Cografi \\
Bilimler & Dergisi \\
\hline & TurkishJournal of GeographicalSciences & e-ISSN:1308-9765 \\
\hline
\end{tabular}

\title{
Rüzgâr Enerji Santrallerinin Ekonomik Etkileri ve Sosyal Kabul: Mucur Örneği
}

\section{Economic Effects of Wind Energy Systems and Social Acceptance: Mucur Case}

\section{Z. Emir Taşkın*a, Mutlu Yılmaz ${ }^{b}$, Çağdaş Kılıçc}

\begin{tabular}{l} 
MakaleBilgisi \\
\hline DOI: \\
10.33688/aucbd.784601 \\
\hline MakaleGeçmişi: \\
Geliş: 24.08 .2020 \\
Kabul: 13.10.2020 \\
\hline AnahtarKelimeler: \\
Yenilenebilir Enerji \\
Rüzgâr Enerjisi \\
Sosyal Kabul \\
Ekonomik Etki \\
Mucur
\end{tabular}

\begin{tabular}{l} 
Article Info \\
\hline DOI: \\
10.33688/aucbd.784601 \\
\hline Article History: \\
Received: 24.08 .2020 \\
Accepted: 13.10 .2020 \\
\hline Keywords: \\
Renewable Energy \\
Wind Energy \\
Social Acceptance \\
Economic Impact \\
Mucur
\end{tabular}

\begin{abstract}
$\ddot{\partial} z$
Çalışma rüzgâr enerji tesisinin bir bölgede kurulmasıyla ortaya çıkan ekonomik faaliyetler ile yerel topluluğun tesisi kabul etme ilişkisine odaklanmaktadır. Bilindiği üzere rüzgâr enerji santralleri kurulduğu bölge için bir kalkınma aracı ve bu yönüyle de yerel halkın desteğini aldı̆̆ ileri sürülmektedir. Bu çerçevede ekonomik etkilerin kolay takip edilebileceği, küçük ölçekli kırsal ekonomiye sahip Kırşehir iline bağll Mucur ilçesinde yer alan Geycek rüzgâr santrali ve çevresinde yer alan yerleşimler araştırma sahası olarak seçilmiştir. Anket ve görüşme tekniğiyle toplanan verilerin analiz edilmesi sonucunda santralin ekonomik etkilerinin sinırlı olduğu, bölge için bir kalkınma enstrümanı olmaktan uzak olduğu ve bu nedenle ekonomik etki demetlerinin kabul süreçleri ile düşük düzeyde etkileşiminin olduğu görülmüş̧ür. Çevre yerleşimlerden santralin inşaat aşamasında sağlanan vasıfsız işgücünün bölge için gerçekleşen en büyük ölçekli fakat dönemlik ekonomik etkinlik olduğu, işletim aşamasında sınırlı sayıda istihdamın devam ettiği ve bunun dışında sürekliliği olmayan alışverişler, kiralamalar ve az miktarda gerçekleşen arazi kamulaştırmalarının ekonomik faaliyetleri oluşturduğu bulunmuştur.
\end{abstract}

\footnotetext{
*Sorumlu Yazar/Corresponding Author: emir.taskinn06@gmail.com

aAnkara Üniversitesi, Sosyal Bilimler Enstitüsü, Ankara/Türkiye, https://orcid.org/0000-0002-0476-9891

bAnkara Üniversitesi, Dil ve Tarih-Coğrafya Fakültesi, Coğrafya Bölümü, Ankara/Türkiye, https://orcid.org/0000-0001-89141165

cAnkara Üniversitesi Sosyal Bilimler Enstitüsü, Ankara/Türkiye, https://orcid.org/0000-0002-0218-2907
} 


\section{Giriş}

Dünya nüfusunun düzenli artış1, sanayileşme, ekonomik gelişmeler ve enerjiye olan bağımlılık enerjinin tüketim miktarını her geçen gün artırmaktadır. Doğal olarak devletler geçmişten günümüze sistemin ihtiyacı olan enerjiyi sağlamak, ortaya çıkabilecek üretim-tüketim açığının önüne geçebilmek, yaşam standartlarını korumak ve siyasi bir manevra aracı olarak enerji politikalarına merkezi bir önem vermektedir. Bu süreçte eşit olmayan mekânsal dağılışına rağmen düşük maliyetleri ve rahat ulaşılabilir olması nedeniyle fosil tabanlı enerji kaynakları hayati yer kaplamaktadır. Her ne kadar son yarım yüzyılda bu kaynaklarla ilişkili siyasi ve çevresel sorunlar yeni kaynakların politika gündeminde ve enerji portföyünde yer bulmasına yol açtıysa da kömür, petrol ve doğal gazdan oluşan fosil tabanlı kaynaklar enerji üretim-tüketiminde hâkim konumunu korumaktadır. Dünyada birincil enerji kaynakları tüketimi 2017 yılında 13,9 milyar ton petrol eşdeğerine ulaşmıştır. Bu tüketimin yaklaşık \%86,2' si de fosil enerji kaynaklarından karşılanmaktadır. Yenilenebilir enerji kaynaklarının oranı ise tüm olumlu gelişmelere rağmen \%13,8 seviyelerindedir (IEA, 2019).

Mevcut enerji kompozisyonunun ağırlıklı yapısının önümüzdeki yıllarda da devam etmesi beklenmekte ve enerji talebindeki artışın (2017-2040 dönemi) büyük bölümünün fosil kaynaklardan karşılanması öngörülmektedir (EÜAŞ, 2020). Fakat fosil enerji kaynaklarının dünyada ciddi çevre sorunlarına yol açması, rezervlerinin yakın gelecekte tükenecek olması ile ilgili senaryolar, fiyat istikrarsızlıkları (enerji güvenliği gibi) nedenlerden dolayı yenilenebilir enerji kaynaklarına olan ilginin korunması söz konusudur (Y1lmaz, 2012). Yaşanan bu ilgiyi pozitif anlamda harekete geçiren tarihi en önemli olay ise 1970'li yıllarda yaşanan petrol krizidir. Yaşanan kriz, ülkelerin yenilenebilir enerji türlerini fosil tabanlı enerji kaynaklarına olan bağımlılığın sonucu olarak ortaya çıkan siyasi, ekonomik ve sosyal sorunlar nedeniyle gündemine almasıyla sonuçlanmıştır.

$\mathrm{Bu}$ süreç içerisinde yenilenebilir enerji kaynakları içerisinde de en fazla gelişen-ticari nitelik kazanan ve verimli kılınan enerji türü ise rüzgâr enerjisi olmuştur. Günümüzde, rüzgâr enerjisi 100' den fazla ülkenin elektrik üretmek için kullandığ yaygın bir enerji türü halini almıştır (Enerji Atlası, 2019). IRENA'nın (2020) raporuna göre dünyada rüzgâr enerjisi kurulu gücü 2010 y1lında 180.850 MW iken, 2019 yılında 622.704 MW'a ulaşmıştır. Türkiye'deki rüzgâr enerjisinin gelişimi de dünyada ki rüzgâr enerjisi gelişimine paralel olarak artış göstermiştir. TUREB'in verilerine göre 2008 yılında Türkiye'de rüzgâr enerjisi kurulu gücü 363,7 MW iken 2019 y1lında 8.056 MW'a yükselmiştir (Şekil 1).

Rüzgâr enerjisi kurulu güç verilerinden görüldügü üzere Dünyada ve Türkiye'de coğrafi olarak yaygın, yenilenebilirlerin iç üretimi açısından önemli bir enerji türü konumuna gelmiştir. Türkiye'de resmi projeksiyonlara göre önümüzdeki 10 yll içerisinde rüzgâr enerjisinde sisteme ilave 10.000 MW'lık radikal bir artış hedeflenmektedir (EÜAŞ, 2020). Ayrıca rüzgâr enerjisi, fosil tabanlı enerji kaynaklarının yol açtığı sorunlara dönük farkındalık, bu alanda üretilmiş bilgi, çevreci hareketler ve medya desteği gibi nedenlerden dolayı son yıllarda yüksek kamuoyu desteği almaktadır. Bununla birlikte rüzgâr enerjisinin farklı coğrafyaları etkileyen dağınık yapısı kurulduğu bölgelerde kamuoyunun genel olumlu tutumundan farklılaşan tepkileri ortaya çıkarmaktadır. Söz konusu durum erken dönemde yenilenebilir enerjilerle ilgili olumlu yaklaşımın baskılamasıyla politikacılar, piyasa aktörleri, akademisyenler ve kamuoyunun geneli tarafından anlaşılamamış/anlamlandırılamamıştır. Artan örnek 
sayısı ve kazanılan deneyimler ile rüzgâr tesislerinin kurulduğu bölgelerde tesislerin çevre sistemlerle sayısız sosyo-kültürel, çevresel, mekânsal ve ekonomik ilgi ve ilişki kurduğu fark edilmiştir.

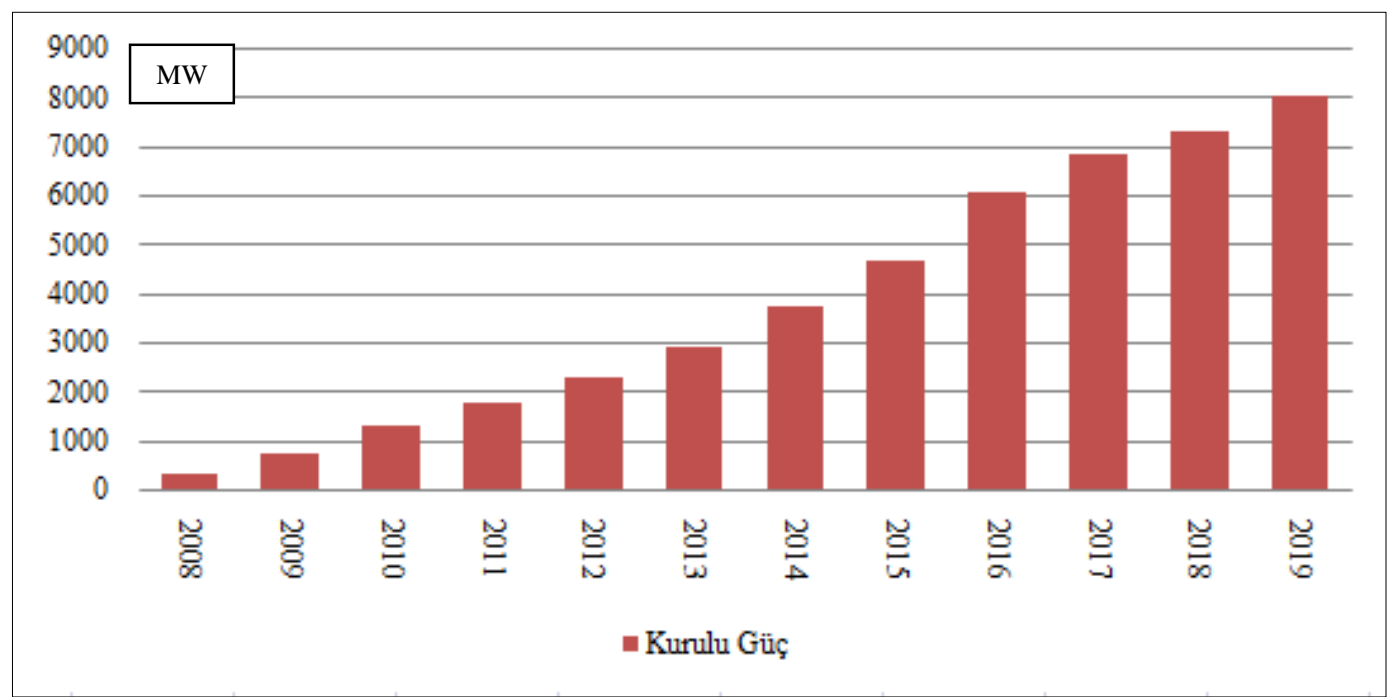

Şekil 1.Türkiye'de rüzgâr enerjisi kurulu gücü gelişimi

Kaynak: TUREB, 2020

Sosyal kabul, yerel toplulukların uygulanacak olan projenin kurulum ve işletim döneminde ortaya çıkan faaliyetlerin topluma olan etkisi ve toplumun bu etkiye karşı bilgileri, düşünceleri, kanıları ve tepkilerinin tamamını içermektedir. Bu yönüyle karbonsuz enerji üretimi ve sürdürülebilir yaşamın yollarını ararken rüzgâr enerji sistemlerinin yayılmasının peyzaj ve yaşam tarzlarını etkilediği ve sonuçta tetiklenen politik, ekonomik, çevresel ve psiko-sosyal uyarıcıların destek kadar muhalif tutum davranışlara da neden olması (Kılıç, vd., 2017) sosyal kabulün bağlamını oluşturmaktadır.

Günümüz akademik ve popüler çalışmaları kavramın genel temalarının çok çeşitli yönlerine odaklanmaktadır. Rüzgâr enerjisinin sosyal kabulüyle ilişkili gürültü etkisi, canlılar üzerine etkiler, demografik özellikler ile ilişkisi, türbin yükseklikleri, planlama, süreçlere katılım, maliyetler ve faydaların dağıtımında adalet gibi konular bunların sadece birkaçını oluşturmaktadır. Uluslararası literatürde önemli sayıda ve detayda yer alan çalışmaların aksine, Türkiye'de rüzgâr enerjisinin sosyal kabulünün dinamiklerini ölçmeye dair çalışmalar sınırlı sayıda gerçekleşmiştir. Mevcut çalışmalar daha çok sosyal kabul alanın genel temaları üzerine literatür taraması ya da farklı enerji türlerinin kabulüne yönelik saha çalışması şeklindedir. Peker (2012), Kılıç vd., (2017), Arslan ve Uzun (2017) çalışmalarında sosyal kabule dair literatürde yer alan tartışmaları incelemiş ve rüzgâr enerjisine yönelik sosyal kabulü şekillendiren faktörleri tartışmıştır. Palabıyık vd. (2010), Uzun ve Arslan (2018) çalışmalarında nükleer enerji ve termik santrallere dönük sosyal kabul dinamiklerini ölçme amacıyla saha çalışması uygulamışlardır.

Çalışmamızın içeriğini oluşturan ekonomik faktörler ülkelerin yasal mevzuatları, teşvik mekanizmaları, demokratik yapısı, kentleşme düzeyi ve sanayileşme gibi nedenlerle çeşitlenmektedir. Rüzgâr enerji santrallerinin kurulduğu bölgeler için ekonomik firsatlar yarattığı, yerel kalkınma aracına dönüşebileceği ve bu yönüyle ev sahibi halkın sosyal kabul tutumunu etkileyeceği iddia edilmektedir. Genel anlamda rüzgâr enerjisinde türbinler, kanatlar, kuleler, nakliye ve tesis işleri sermaye gerektiren 
yatırımlardır ve bunlar makro ölçekte gerçekleşen işlerdir. Şenel ve Koç’a (2015), göre tüm yatırımların \% 75'i türbinlerin üretimiyle alakalı işlere gitmektedir. Bununla birlikte tesisler inşaat sürecinden başlamak üzere kurulduğu bölgelerde ortalama 12 ay süren dönemlik vasıflı ve vasıfssı işçiler için önemli istihdam sağlamaktadır. Tesisin işletme süreci başladıktan sonra sürekli işler de ortaya çıkmaktadır. Söz konusu istihdamın projenin yapısına göre çeşitli oranlarda yerel iş gücünden oluşturulduğu bilinmektedir. Ayrıca elektrik üretiminden elde edilen gelirler, arazi sahiplerine arsa kira ödemeleri, tesislerin yönetiminde yeni modellerin yaygınlaşması (kooperatifçilik, pay ortaklığı vs.), topluluk kalkınma fonlarına katkılar, tesisleşme etkisi, emlak vergisi ödemeleri ile bölgenin özelliği ve ihtiyaçları doğrultusunda yerel topluma ekonomik katkılar da gündeme gelmektedir.

Mevcut pratikler ise uygulama alanlarının birçoğunda halk-devlet ve uygulayıcı firma arasında tanımlanmaya/bilgisine muhtaç itilafların olduğu yönündedir. Bu itilafların kaynağı olabilecek faktörlerin akademik bir ilgiyle bilgisinin üretilmesi, konuyla ilgili akademik üretimlerimizin sınırlılığ1 göz önünde bulundurulduğunda zorunlu gözükmektedir.

Tüm bunların 1şığında ekonomik girdilerin ve etkilerinin daha rahat takip edileceği, kırsal ilişkilerin hâkim olduğu ve küçük tarım ekonomisine sahip Kırşehir iline bağlı Mucur ilçesinde yer alan Geycek rüzgâr santrali çevresinde saha çalışması gerçekleştirilmiştir. Yapılan saha çalışmasıyla bölgedeki ekonomik faaliyetlerin belirlenmesi, santral faaliyetiyle gerçekleşen ekonomik etkilerin bölge insanı tarafından nasıl değerlendirildiğinin görülmesi ve bu değerlendirmelerin genelde rüzgâr enerjisi, daha dar anlamda rüzgâr santraline yönelik tutumlara etkisini ölçmek ve sosyal kabulü dikkate alacak politikaların geliştirilmesine katkı sunmak hedeflenmektedir.

\section{Literatür Değerlendirmesi}

Farklı ülke ve saha örnekleri üzerinde yapılan akademik çalışmalar, ekonomik faaliyetlerin çeşitli ölçek ve biçimlerde gerçekleştiğini göstermektedir. Rüzgâr enerjisinin ekonomik etkileri ülke (Graziano, 2017; Lecca vd. 2017) veya yerel düzeyde (Okkonen ve Lehtonen, 2016; Osterberg ve Distler, 2003) ele alınabilmektedir. Tesislerin makro ölçekte yatırıma, Gayri Safi Yurtiçi Hasılaya (GSYIH), ilişkili sektörlere ve istihdama etkilerinin olduğu ileri sürülmektedir. Graziona vd. (2017) çalışmalarında açık deniz rüzgâr teknolojileri İngiltere'nin GSYİH'sini artırarak 2020'ye kadar ortalama 40.000 tam zamanl1, 2030'a kadar ise 60.000 tam zamanlı bir iş yaratma potansiyeline ulaşılacağından bahsetmektedir. Mevcut enerji politikaları çerçevesinde istenilen hedeflere ulaşıldığında, GSYH'yı yıllık bazda \% 0,03-0,15 artıracağı ön görülmektedir. Sonuç olarak yatırımlar için ülke dışından ithal edilen mallarının oranının azalacağı, yerel üretimin oranının desteklenmesi ve artması ile gelişen rüzgâr enerjisi teknolojisi sayesinde GSYİH'de önemli artışlar yaşanacağı ve daha fazla insanın istihdam şansı yakalayacağı belirtilmektedir. Büyük çaplı ekonomik etkilere odaklanan çalışmaların ortak noktası herhangi bir düzeyde gerçekleşecek değişimin ekonominin doğası gereği doğrudan ya da dolaylı bir biçimde yereli etkileyeceği yönündedir.

Munday vd. (2011), rüzgâr enerji sahalarının yerel alanlara ekonomik katkılarını; “a) Geleneksel ekonomik faydalar (kira getirisi, müteahhitlik hizmetleri, istihdam vb.), b) Yerel topluluklara mali yardımlar (topluluk mülkiyeti, fonlar, sponsorluklar, ucuz elektrik vb.), c) Yerel son y1llarda varlık ve tesisler türünden katkı (peyzaj geliştirme, turizm tesisleri, yol vb.), d) Sağlanan diğer yerel hizmetler 
(eğitim ziyaretleri vb.) ve e) Geliştirme sürecindeki yatırımlar olarak sıralamaktadır”(Kılıç vd. 2017). Osterberg ve Distler'in (2003), yaptıkları çalışmada, ABD'deki Lowa bölgesinde kurulan rüzgâr enerji santralinden Lowa çiftçileri ve toprak sahiplerinin önemli ölçüde kazanç elde ettiğini belirtmiştir. Bir Iowa çiftçisine, her türbin için 2000 ila 4.500 \$ arasında bir yıllık kira ödemesi yapıldığı, ayrıca Clear Gölü ve Storm Gölü yakınlarındaki yaklaşık 115 arazi sahibine yılda yaklaşık 640,000 \$ ödendiği belirtilmektedir.

Mulvaney vd. (2013), ABD’de Benton County bölgesindeki rüzgâr enerjisi santralinin ekonomik etkisini anlamak için anket tekniği kullanarak saha çalışması gerçekleştirmiştir. Çalışma sonucunda yerel halkın endişeleri olsa da, ekonomik faydaların da etki etmesiyle büyük ölçüde rüzgâr enerjisini kabul eden bir topluluk olduğu ortaya çıkmıştır. Bristow vd. (2012), Mulvaney vd. (2013)'in bulgularının aksine, Galler'de, tesislerden gelen ekonomik teşviklerin oldukça marjinal olduğu sonucuna varmış, bu nedenle Galler'deki yerleşmelerin rüzgar enerjisi projelerine devam etme konusunda çok az ilgisi olduğunu belirtmektedir.

Bir başka çalışmada Munday vd. (2011), Galler'deki rüzgâr enerji sistemlerinin ekonomik faydalarını anlamak için yarı yapılandırılmış görüşmeler uygulamıştır. Yapılan görüşmeler sonucu rüzgâr enerji santralinin yerel halka ekonomik olarak sınırlı bir etkisi olmuş, bunun sonucunda, rüzgâr enerjisi firmaları muhalefetle karşı karşıya kalmıştır. Ayrıca Toke vd. (2008) kırsal bölgelerde rüzgâr santrallerinin sağladığı ekonomik faydaların yetersiz olması, Birleşik Krallıkta rüzgâr enerjisine karşı halk tarafından çeşitli bariyerlerin yaratılması ve çatışmaların yaşanmasında etkili olduğunu belirtmektedir.

Bauwens (2015), çalışmasında yerel halk ve yöneticilerle anket çalışması uygulamıştır. Çalışma sonucu, rüzgâr enerjisi yatırımlarında uygulanan bir model olan kooperatiflerin, rüzgâr türbinlerine yönelik tutumlar üzerinde güçlü bir pozitif etkiye sahip olduğunu ve katılımcı programların önemini doğruladığını göstermektedir.

Slattery vd. 2011 yılında yaptığı çalışmada, Batı Teksas'daki dört yerleşmede rüzgâr enerjisi gelişiminin ekonomik etkilerini değerlendirmek ve 100 mil yarıçapında etkilerini ölçmeyi amaçlamıştır. Çalışmada projede inşaat aşamasında çalışan işçileri, kullanılan malzemelerin üretimi yoluyla ortaya çıkan çeşitli ekonomik etkileri incelenmiştir. Sonuç olarak rüzgâr enerjisi projelerine katılımı daha sınırlı olan çok kırsal topluluklar için, bu projelerin ekonomik etkisinin büyük bir kısmının, bireysel projelerin yapıldığı yer dışında tahakkuk etmesi muhtemel olduğu sonucu çıkmıştır. Bu çalışma aracılığıyla yerel ekonomik etkisinin derecesi öğrenmeye çalışılmış ve örnek olması gerektiği düşünülmüştür.

Sosyo-ekonomik etkiler ve kabuller üzerine derinlemesine görüşme ve anket yapılan bir diğer çalışma Greene ve Geisken'e (2013) aittir. Bu çalışmada, Oklahoma'daki rüzgâr enerji santralinin yerel ve büyük paydaşlarının algılarını ölçmek hedeflenmiştir. Bu kapsamda ekonomik etkileri ve kabulleri ölçmek amaciyla karma bir yöntem izlenmiştir. Anket, derinlemesine görüşme ve ekonomik modelleme yöntemleri kullanılmıştır. Çalışma sonucunda yerel halka inşaat aşamasında ve sonrasında ekonomik olarak fayda sağlaması ve kırsaldaki hareketliliği artırması topluluk tarafından itirazların az olmasına ve kabul oranının yüksek seviyede olmasını sağlamıştır. 
Yine ekonomik kabulü derinlemesine incelemiş bir çalışmayı da Holburn (2015) y1lında yapmıştır. Bu çalışmada, Ontario'daki rüzgâr enerji santralinin Aborjin grupları üzerindeki ekonomik kabul boyutunu incelemektedir. Rüzgâr santrallerinin bölgeye yeni iş olanakları yaratması, vergi ödemeleri, arazi sahiplerinin satın alma veya kiralama yoluyla ekonomik doyum sağladığı görülmüsşür.

\section{Yöntem}

Çalışmada nitel ve nicel araştırma tekniklerinin bir arada uygulandığı karma yöntem kullanılmıştır. Bu kapsamda Mucur ilçesindeki rüzgâr santralinin bulunduğu bölgenin yakınındaki köylerde yaşayanlarla anket çalışması gerçekleştirilmiştir. Ayrıca köy muhtarları ve yerel yöneticilerle de yarı yapılandırılmış görüşmeler gerçekleştirilmiştir. Örneklemin seçileceği yerleşimlerin saptanmasında Geycek rüzgâr santrali merkeze alınarak etki analizi için azami 2500 metre zon sınırı belirlenmiştir. Bu sınır ülke, bölge ya da çalışmacılara göre farklılık göstermekle beraber (Braunholtz, 2003; Warren vd., 2005; Swofford ve Slattery, 2010; Brown vd., 2012)çalışma sahasının topografik özellikleri dikkate alındığı zaman 2500 metrelik sınırın kapsayıcılığı yüksek bulunmuştur. Bu azami sınırın içinde yer alan Geycek, Budak, Büyükburunağıl, Küçükburunağıl ve Obruk köylerinden oluşan 5yerleşme alanı çalışma sahası olarak belirlenmiştir. Kurugöl köyü ise belirlenen sınırlar içerisinde yer almamasına rağmen enerji nakil hatııın arazilerinden geçmesi nedeniyle çalışmaya dâhil edilmiştir (Şekil 2). Bölgenin haritası konum verileri işlenerek ArcGIS 10.1 programında oluşturulmuştur.

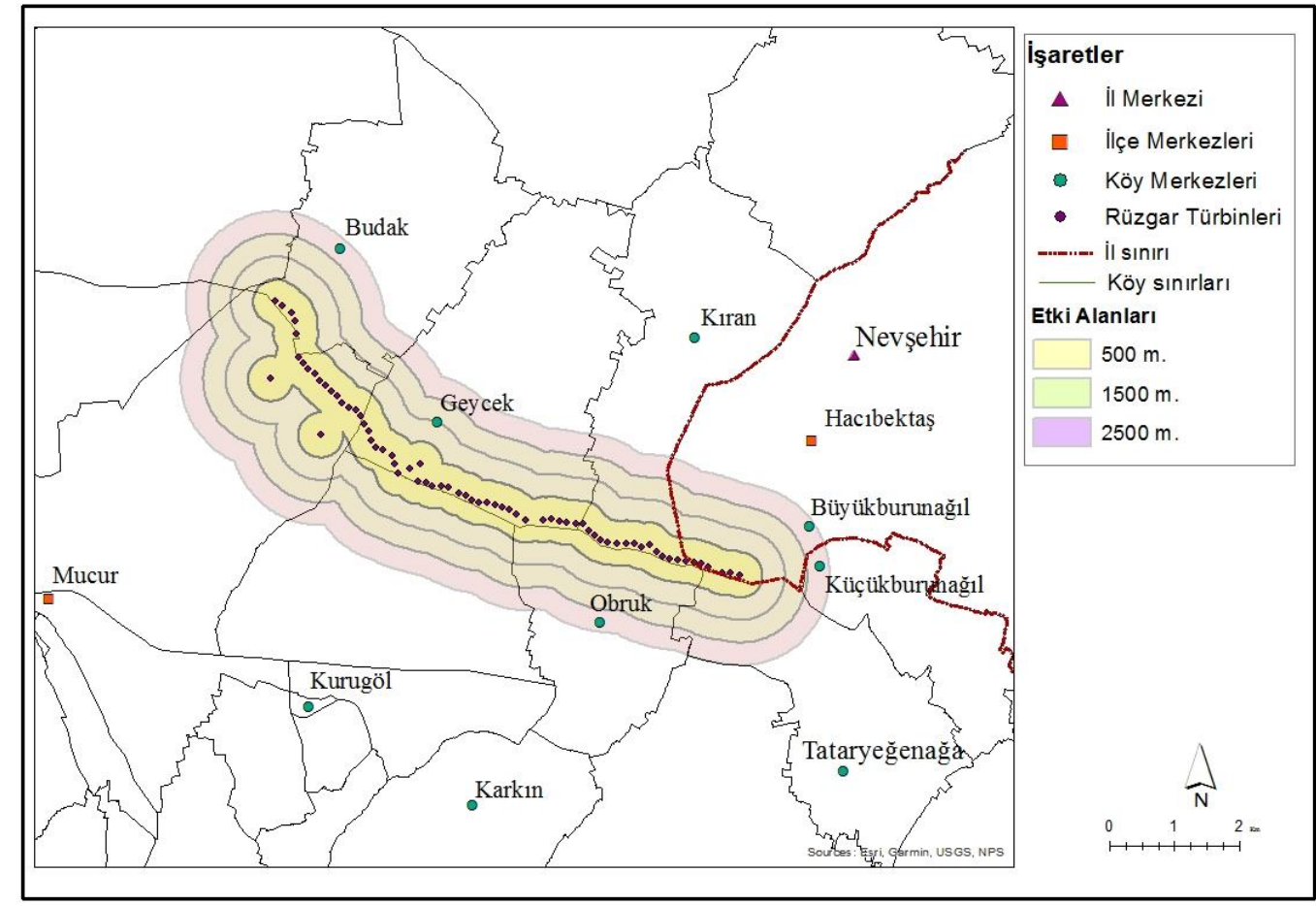

Şekil 2. Geycek rüzgâr santrali etki sınırı

Anket uygulanacak örneklemin belirlenmesi için TÜIK'de yer alan Adrese Dayalı Nüfus Kayıt Sistemi'nin (ADNKS) verilerinden faydalanılmıştır. Köylerde nüfusun az olması araştırmanın önemli kısıtlarından biridir. Bu kısıtll1ık ve mevcut kişilere ulaşmakta yaşanan sorunlar nedeniyle\% 10 güven aralığına göre örneklem sayısı hesaplanmıştır. Bu kapsamda köylerden Büyükburunağıl'da224, 
Obruk'da44, Kurugöl'de 540, Küçükburunağ1l'da128, Geycek'de102 ve Budak'da125 kişi olmak üzere toplam 1163 kişiye ulaşan nüfus içerisinden 89 anket sayısına ulaşılmıştır. Farklı tarihlerde gerçekleştirilen 5 saha ziyaretiyle 91 kişiye anket uygulanmıştır. Ayrıca yapılan görüşmeler veride elde edilen doyum noktası ve tekrarlar dikkate alınarak 8 katılımeıda sonlandırılmıştır.

Arazi çalışması sırasında uygulanan anketlerde likert ölçeği biçiminde yapılandırılmış sorular sorulmuş ve cevap alınmıştır. Elde edilen veriler SPSS-PASW programı kullanılarak analiz edilmiştir. Araştırmanın nitel kısmında literatür çerçevesinde belirlenen temalar ekseninde görüşmeler gerçekleştirilmiş ve deşifre edilen veriler betimsel analize tabi tutulmuştur. Altunışık vd. (2010:322) betimsel analizin bir çerçeve oluşturma, tematik çerçeveye göre verilerin işlenmesi, bulguların tanımlanması ve bulguların yorumlanması şeklinde belirttiği dört aşama çalışmanın hedefleri ile örtüşmüştür.

\subsection{Araştırma Sahası}

Araştırma sahası olan Mucur ilçesi, İç Anadolu Bölgesi’nin Orta Kızılırmak Bölümü’nde Ankara ile Kayseri illeri arasında geçiş güzergâhı konumundadır. Mucur ilçesi Kırşehir'in güneydoğusunda yer almaktadır (Şekil 3).

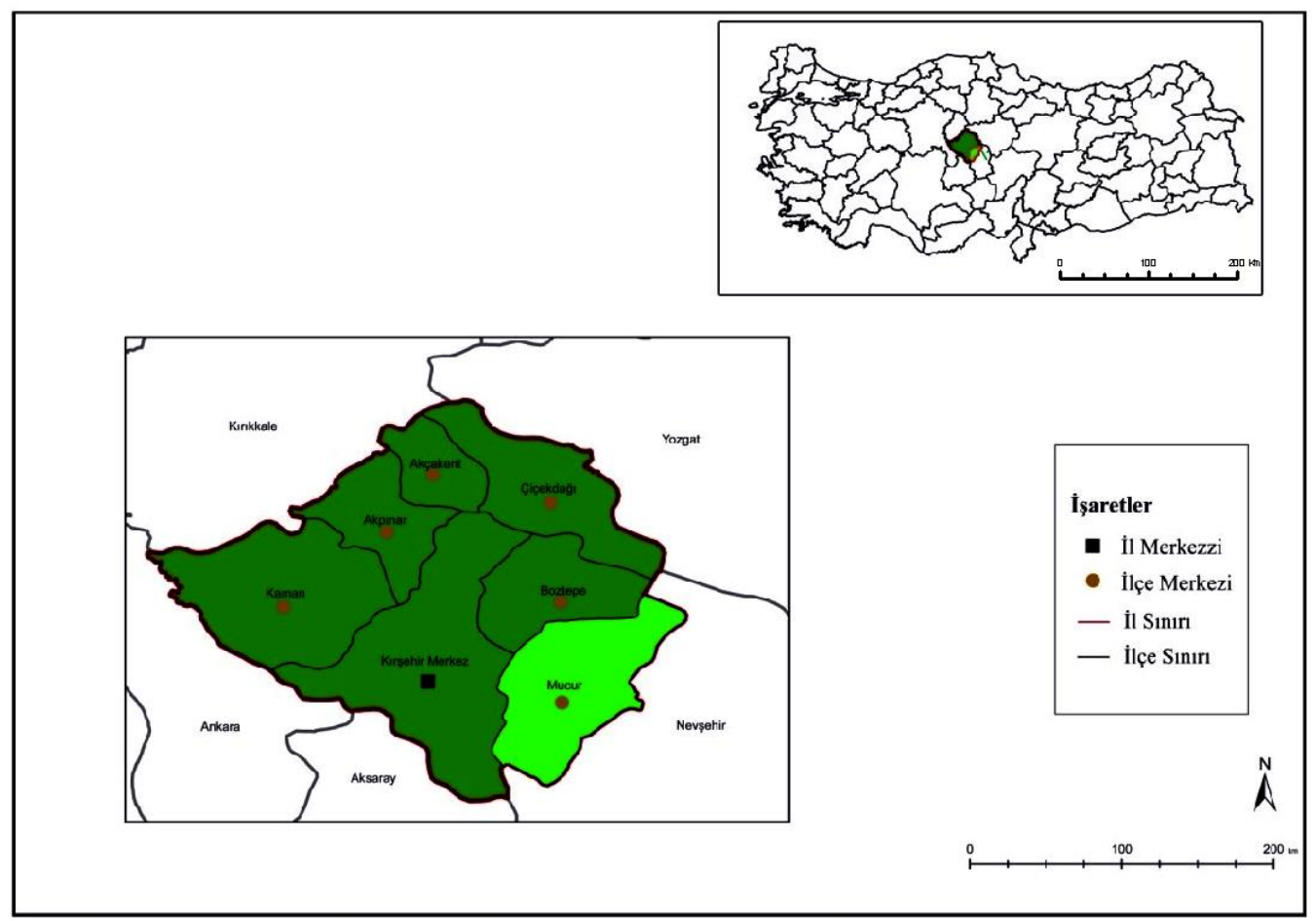

Şekil 3. Mucur ilçesi lokasyon haritası

İlçenin 2007-2019 yılları arasındaki nüfus verileri incelendiğinde, hem köy hem de şehir nüfusunda değişim yaşandığı görülmektedir. Mucur'da 2007 yılında 19.445 olan toplam nüfus 2019 y1lına gelindiğinde 18.536'ya gerilemiştir. Görüldüğü gibi toplam nüfusta bir azalma söz konusudur. Bu dönem içerisinde ilçe merkezini oluşturan Mucur şehir nüfusu ise 11.984'ten 13.040'a çıkmıştır. Aynı dönem içerisinde kırsal nüfusu oluşturan köy nüfusunda ise ciddi bir azalma söz konusudur. 2007 yılında 
7.461 olan köyler nüfusu 2019 yılına gelindiğinde 5.496 kişiye gerilmiştir (Çizelge 1). Bu durum Türkiye'nin genel nüfus değişimi ile paralellik göstermektedir. Ülke genelinde olduğu gibi Mucur'da kır nüfusu azalmakta, şehir nüfusu ile artmaktadır.

Çizelge 1.Mucur ilçesinin köy ve şehir nüfusu

\begin{tabular}{llll}
\hline Y1llar & Köy & Şehir & Toplam \\
\hline 2007 & 7.461 & 11.984 & 19.445 \\
2011 & 6.440 & 12.402 & 18.842 \\
2015 & 5.613 & 12.741 & 18.354 \\
2019 & 5.496 & 13.040 & 18.536 \\
\hline
\end{tabular}

Kaynak: TÜiK, 2020

Mucur ilçesi İç Anadolu bölgesinde yer almasından dolayı karasal iklim özellikleri göstermektedir. Sıcaklık ve yağış grafiği incelendiğinde (1930-2018), maksimum yağışın ilkbahar ayında en düşük yağışın ise yaz aylarında düştügü görülmektedir. Buna ek olarak MGM'nin verilerine göre y1llık yağış ortalama yağış miktarı 400 mm civarında gerçekleşmektedir (MGM, 2020). İlçe en sıcak dönemi $23^{\circ} \mathrm{C}$ sıcaklık ortalaması ile temmuz ve ağustos aylarında yaşamaktadır(Şekil 4). En soğuk dönemi ise $-0,2^{\circ} \mathrm{C}$ ile ocak ayında yaşamaktadır ve ilçenin sıcaklık ortalaması yıllık $11,5^{\circ} \mathrm{C}$ ' dir.

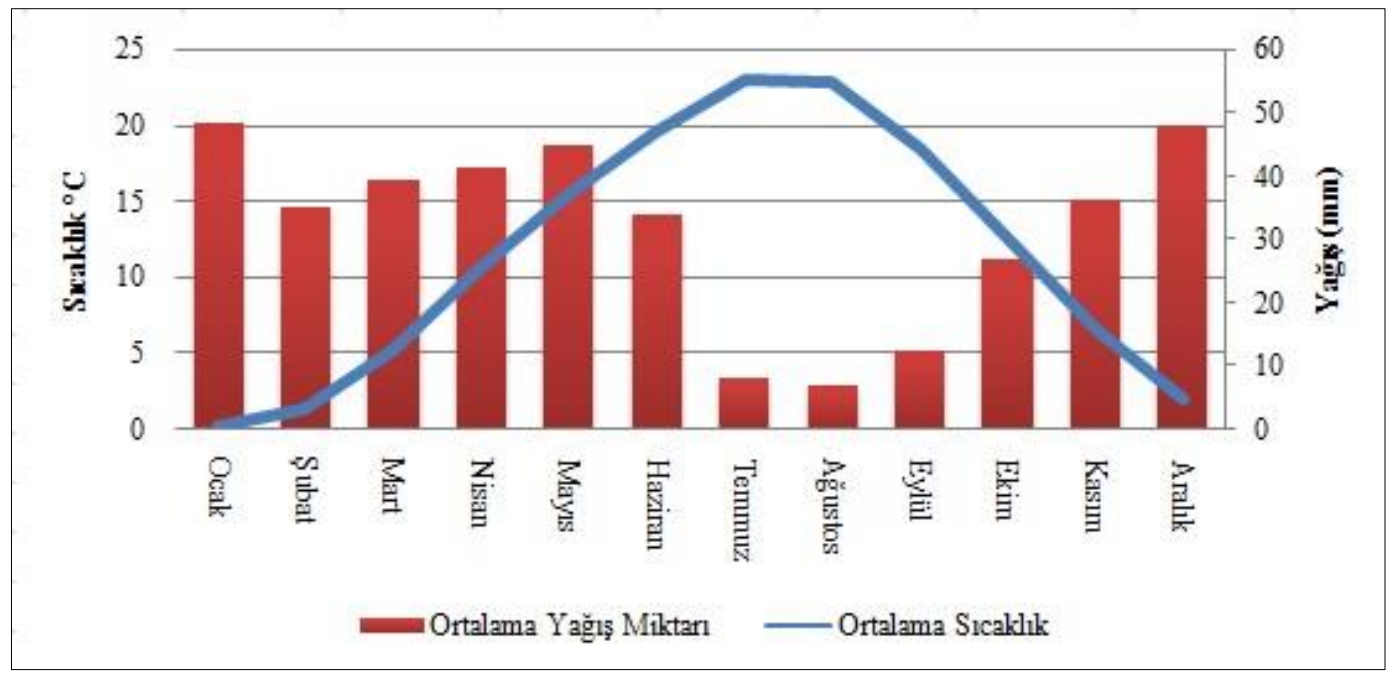

Şekil 4. Mucur ilçesinin yıllık ortalama sıcaklık ve yağış grafiği 1930-2018

Kaynak: MGM, 2020

Bölgede hâkim olan karasal iklimin özelliklerine uygun olarak Mucur ilçesinde tahıl üretiminin ön planda olduğu görülmektedir. İlçede 2019 yılı itibariyle 47.134 ton arpa, 35.110 ton buğday,645 ton yulaf, 115ton çavdar üretimi yapılmıştır. Ayrıca 126.000 ton şekerpancarı, 8.881 ton nohut, 4.507 ton mısır, 3.000 ton yonca ve1.116 ton ayçiçeği üretimi gerçekleştirilmiştir. Tarıma ek olarak hayvancılıkta bölgede önemli bir gelir kaynağı olarak görülmektedir. Bu kapsamda ilçede 2019 itibariyle büyükbaş süt üretimi miktarı 14.971,525 ton, küçükbaş ise 1.140,36 ton gerçekleşmiştir (TÜiK, 2020). İlçede Kızıldağ, Yeniyapan ve Avcı köylerinde 3 adet Tarım Kredi Kooperatifi bulunmaktadır. Bu 
kooperatiflerin 1300 ortağı olup 18 köy mevcut kooperatiflere bağlı durumdadır. Tarım ve hayvancılığa ek olarak, ilçede 142 iş yeri bulunan sanayi sitesi, 5 adet un fabrikası ve 1 adet mermer fabrikası bulunmaktadır (Mucur Belediyesi, 2020).

\section{Bulgular}

Çalışma bulguları literatürde yer alan rüzgâr enerji tesislerinin sosyal kabulle ilişkilendirilen ekonomik temaları üzerinden anlaşılmaya çalışılmaktadır. Giriş bölümünde değinildiği üzere rüzgâr enerji tesislerinin yerel ekonomik etkileri çeşitli biçimlerde gerçekleşmektedir. Bu fayda ya da ekonomik faaliyet demetlerinden Danimarka, Almanya gibi birçoğunu aktif kullanan ülkeler yanında bunların oldukça sınırlı olarak gözlemlendiği İngiltere, Fransa gibi ülkeler de bulunmaktadır. Türkiye de mevzuat ve pratik örnekler açısından konuya bakıldığı zaman teşvik mekanizmalarının/ekonomik faydaların ağırlıklı olarak yatırımcılara tanımlandığı ya da yerli malı kullanımında tanımlanan teşvik gibi piyasa dinamiklerini sürece dâhil etmek gibi bir fonksiyonunun bulunduğu görülmektedir. Bunun yanında tesislerin kurulduğu bölgelerde yaşayan insanlara dönük plan-inşaat ve işletim aşamalarını kapsayan sistematik ekonomik faaliyet ya da faydaların tanımlanmadı̆̆ı, devlet veya piyasa aktörleri için bu türden sorumlulukların bulunmadığı bilinmektedir. Çalışmamız açısından konunun düzenlemeler/mevzuat boyutu kapsam dışıdır ve başka bir araştırma bünyesinde ele alınacaktır. Bununla birlikte Geycek' de düzenli olmamakla beraber tesis sahibi firma ve yerel halk arasında gerçekleşen ekonomik faaliyetler ve bunların yerel bölge insanı tarafından algılanması beş başlık altında kategorize olmaktır. Bunlar;

+ Kurucu firma ve taşeronlarının çalıştırdığı personelin ilçe merkezi ve ilgili köylerde barınma, yeme-içme veya basit kiralamalar üzerinden oluşturdukları ekonomik etkinlikler,

+ Kamulaştırma, satın alma veya kiralama süreçleriyle oluşan ekonomik etkinlikler,

+ Kurulum ve işletim aşamasında bölge insanından sağlanan işgücü,

+ Bölgede süregelen mevcut ekonomik faaliyetler, değerler ve santral faaliyetinin etkileşimi sonucu oluşan ekonomik durum/etkileşim,

+ Ekonomik etkiler ve sosyal kabul biçimindedir.

\subsection{Katılımcıların Sosyo-Demografik Özellikleri}

Araştırma sahasının kırsal özellik taşıması ve bölgenin dışarıdan gelenler için kısmen kapalı bir toplum olması nedeniyle yerel bağlantılarla saha çalışmasına girilmesine/ortak hareket edilmesine rağmen kadın katılımcılara ulaşılmasında sorunlar yaşanmıştır. Tüm bu sorunlara rağmen anket kısmında kadın katılımcı oranında \%41,8 ile önemli bir sayıya ulaşılmışıı. Görüşme yapılan katılımcılar incelendiğinde, 2 kişi dışında bütün katılımcılar yerleşik olarak kırsal ekonomik faaliyetleri sürdürmektedir ve meslek olarak kendilerini çiftçi olarak tanımlamaktadır (Çizelge 2). Ankete katılanların içerisinde ise tarım ile geçinenlerin oran $1 \% 44$ 'dür. 
Çizelge 2. Araştırma sahasında görüşme yapılan katılımcılar listesi

\begin{tabular}{llll}
\hline & Yerleşme & Meslek & Görüşme Tarihi \\
\hline K1 & Geycek & Çiftçi & 26.08 .2018 \\
K2 & Budak & Çiftçi & 26.08 .2018 \\
K3 & Obruk & Çifţi & 26.08 .2018 \\
K4 & Küçükburunağ1l & Çiftçi & 26.08 .2018 \\
K5 & Büyükburunağ1l & Çitfçi & 13.09 .2018 \\
K6 & Kurugöl & Çiftçi & 13.09 .2018 \\
K7 & Mucur & Memur & 13.10 .2018 \\
K8 & Mucur & Tekniker & 13.10 .2018 \\
\hline
\end{tabular}

Yaş değişkenine göre, katılımcılar içerisinde en önemli kümeyi \%55,2 ile 46-65 yaş arası nüfus oluşturmaktadır. Bunda en önemli neden Türkiye de kırdan kente göç, tarımda yüksek maliyetler, tarımsal faaliyetlerin ekonomik değer üretmede değişkenliği ve yetmeme hali, sosyolojik olarak ise çiftçiliğin düşük statülü işler arasında görülmesi nedeniyle genç nüfusun kent merkezlerini/büyük şehirleri tercih etmesidir (Çizelge 3).

"Mazot gübreye güç yetmiyor. Verdiğini alma garantin de yok. Kurakllk olur ürün alamazsın, çok yağış olur alamazsın. Satarsın para alamazsın. Bak nohut kaldı elde ”(K6).

"Hayvancılık yapacak genç bulamıyoruz. Bizim köyde yaşı büyük bir kişi kaldı. Civar köylerde tanıdıklar var hayvancılık için Afgan birini tutmuş" (K3).

Çizelge 3. Katılımcıların demografik özellikleri

\begin{tabular}{ccc}
\hline Değişken & & Yüzde (\%) \\
\hline Cinsiyet & Kadın & 41,8 \\
& Erkek & 58,2 \\
\hline Yaş & $0-18$ & 2,0 \\
& $18-25$ & 1,0 \\
& $26-45$ & 21,4 \\
& $46-65$ & 55,2 \\
\hline Eğitim & $65+$ & 20,4 \\
& Herhangi Bir Okulu Bitirmemiş & 6,1 \\
& İlkokul & 53,1 \\
& Ortaokul & 10,2 \\
& Lise & 21,4 \\
Gelir Düzeyi & Üniversite & 9,2 \\
& $0-1000$ TL. & 20,4 \\
& $1001-2000$ TL. & 56,1 \\
& $2001-3000$ TL. & 13,3 \\
& $3001-4000$ TL. & 5,1 \\
& $4001-5000$ TL. & 4,1 \\
& 5001+ TL. & 1,0 \\
\hline
\end{tabular}

Eğitim yönüyle katılımcıların durumuna bakıldığı zaman $\% 53,1$ oran ile ilkokul mezunları ağırlığı oluşturmaktadır. Buna karşın \%9,2' lik üniversite mezunu oranı emeklilik sonrası ikinci bir yaşam alanı olarak mevsimsel memleketine gelen, ayrıca gelirlerini destekleyecek tarımsal faaliyetlerde bulunan profesyonellerden oluşmaktadır. Bu kişiler ağırlıklı olarak Kırşehir - Mucur merkez ya da çevre iller Kayseri ve Ankara da yaşamaktadır. 
“...yıllarca Almanya yaşadım, çalıştım geldim şimdi ceviz bahçem var yazları onunla ilgileniyorum. Oğlum şimdi Ankara'da oturuyor onun düğ̈̈n̈̈ü bile bu bahçede yaptım" (67 nolu anket 26/08/2018, Erkek).

Gelir düzeyi açısından çalışmaya katılanlar incelendiği zaman sürekli tarım faaliyetinde bulunanların düzenli bir gelir beyan edemediği fakat aylık olarak düşünüldüğünde $\% 56,1$ oranı ile 1001 2000 TL arasında gelire sahip olduğu görülmektedir. Bu oranı \% 20,4 ile 0-1000 TL arası gelir grubu takip etmektedir. Dolayısıyla katılımcıların $\% 76,5$ 'i düşük gelir seviyesi içerisinde yer almaktadır (Çizelge 3).

\subsection{Rüzgâr Santralinin Ekonomik Etkileri ve Sosyal Kabul İle İlgili Bulgular}

Araştırmadan elde edilen bulgular beş kategoride sınıflandırılarak sunulmuştur. Bunlar:

Kategori 1: Kurucu firma ve taşeronlarının çalıştırdığı personelin ilçe merkezi ve ilgili köylerde barınma, yeme içme veya basit kiralamalar üzerinden oluşturdukları ekonomik etkinlikler

Yenilenebilir enerji sistemlerinin sosyal kabul süreçleriyle ilgili literatür incelendiği zaman kırsal alanlarda yürütülen tesis proje ve inşaat aşamasında çalışan, bölgeye dışarıdan gelen insanların bu bölgelerde ticareti hareketlendirdiği belirtilmektedir. Barınma hizmetleri, yeme-içme ve bölge insanından ev, araç vb. yapılan kiralamalar bu hareketliliğe yol açan faaliyetler olarak gösterilmektedir. Leistritz ve Coon (2009), Amerika'nın Kuzey Dakota'daki çalışmasında rüzgâr santralinin inşaat aşamasındaki işçilerin yerel bölgelerdeki barınma ve yeme-içme gibi faaliyetleri gerçekleştirerek ekonomik fayda sağladığını belirtmektedir. Cohen (2010), Kuzey Dakota'daki 150 MW'lık bir Kuzey Dakota rüzgâr santralinin çeşitli ekonomik aktivitelerle yerel ekonomiye 3.2 milyon dolarlık ekonomik fayda sağladığını ifade etmektedir.

Araştırma sahasında görüşme ve anketlerin uygulandığı katılımcılar, Geycek rüzgâr santralinin yapımını üstlenen firmanın bölge dışından gelen çalışanlarının inşaat aşaması ve devam eden işletim aşamasında çeşitli ihtiyaçlarını Mucur ilçesinden sağladığını belirtmektedirler. Fakat bu faydanın ekonomik hareketliliğe yol açacak ölçekten uzak olduğu ve kişisel düzeyde küçük gelir getiren ticari ilişkilerden ibaret olduğu görülmektedir/anlaşılmaktadır.

"Fayda sağladı, esnaf para kazand yemeklerini yediler. Marketi kullandılar giysi ve ayakkabı aldılar. Fakat fazla bir fayda değil bu” (68. Anket 26 /08/2018, Erkek).

"Santralin ihtiyaç duyduğu çay, şeker gibi malzemeleri Mucur merkezden alıyoruz. Enorcon ekibi İzmir'den geldiği için otellerde kaldl" (K7).

Ayrıca bu değerlendirmeler anket sonuçlarıyla da uyumluluk göstermektedir. Ankette yer alan "Santralin inşaat proje ve işletim esnasında bölge insanından ticaret yapılmıştır." sorusuna verilen cevaplar incelendiğinde, $\% 67,4$ oranında olumsuz cevap vererek yerel halkın bölge ile ticaret yapıldığına dair düşüncesinin negatif olduğunu göstermektedir. Benzer şekilde "Santralin proje, inşaat, işletim aşamasında görev yapan işgücü bölgeye gelir getirmektedir.” sorusuna da katılımcılar \%65,6 oranıyla olumsuz bakmışlardır. Bu soruya gelir getirdiği yönünde olumlu görüş bildiren oranı ise $\% 11,1$ ile düşük seviyelerde gerçekleşmiştir. 
Bölgelerin teknik kapasitesi, sanayisinin gelişkinliği ve ticari faaliyet çeşitliliği (taş ocakları, beton fabrikası, vinç kuleleri vb.) bölgenin ticaret yapabilme kapasitesini arttırmaktadır. Bu yönüyle soyut bir kavram olan bölgenin de kendi içinde yukarıda değinilen kapasitelerle ilişkili olarak hiyerarşik yapılar meydana getirdiği görülmektedir.

"Vinci Mucurdaki insanlardan almadılar kendi şirketlerinin vincini getirip kullandılar" (68. Anket 26/08/2018, Erkek).

“...Aşağı lokantada yemek yediler (Mucur ilçe merkezi) ama köye (Obruk)- köylere bir faydaları olmadı. Sadece bizim köyden traktörü olan birinin traktörünü kullandılar" (71. Anket 26/08/2018, Erkek).

Kategori 2: Kamulaştırma, Satın Alma Veya Kiralama Süreçleriyle Oluşan Ekonomik Etkinlikler

Çalışma sahasında karşılaşılan diğer ekonomik etkinlik ise tesis ve enerji nakil hatları güzergâhına giren tapulu arazilerin kiralama, satın alma ya da kamulaştırma yoluyla el değiştirmesidir. Holburn (2015) çalışmasında, Haldunand bölgesindeki tüm rüzgâr santralleri için yıllık kira ödemelerinin yaklaşık 7 milyon dolar olacağını hesaplamakta 20 yıl için toplam ödemelerin 142 milyon dolara ulaşmasını beklemektedir. Lantz ve Tegen (2009) ise çalışmasında ABD'de yerel ekonomik etkileri hesaplayarak Nebraska'daki kapasite gücü 7 bin $800 \mathrm{MW}$ olan rüzgâr santralinin toprak sahiplerine yıllık arazi kiralama ödemelerinin 27 milyon ila 32 milyon dolar arasında olduğunu ifade etmektedir.

Bununla birlikte kiralama, satın alma gibi faaliyetlerin her zaman olumlu ekonomik etkiler üretmediği, çeşitli nedenler ve bir takım bölgeye özgü koşullar nedeniyle mülk sahipleri aleyhine sonuçlar doğurduğu görülebilmektedir. K1lı̧ vd.'nin (2017) belirttiği üzere arazinin reel değeri, bölgenin niteliği ile ilişkili rant beklentisi (turizm, konut, tarım alanı gibi) ve arazinin manevi anlamı türünden gerekçeler nedeniyle bir çok tesis alanında halk-devlet ve firma arasında itilaf ve anlaşmazlıklar bulunmaktadır.

"Şahısların arazilerini istimlak ettiler. Bu durum kişileri memnun etti. Kıymetli tarım arazisi değildi öyle olunca işlerine yaradı" (K2).

Geycek rüzgâr santralinin kurulduğu bölgede yer alan arazilerin büyük kısmı devlete ait mera alanlarıdır. Dolayısıyla proje nedeniyle kamulaştııılan, satın alınan ya da kiralanan arazi miktarı sınırlı gerçekleşmiştir. Fakat ENH'nin (Enerji Nakil Hattı) geçtiği Kurugöl köyünde satın alma faaliyetleri daha yoğun gerçekleşmiştir. Satın alınan arazilerde alan olarak büyük araziler değildir. Enerji nakil hattından dolayı tarlalarda direklerin geçtiği araziler kamulaştırılmıştır. Görüşmecilerin genel yönelimi tarlaların makul fiyat karşılığında alınmış veya kamulaştırılmış olduğu yönündedir.

"Tatmin etmediler. Bildiğgim kadarıyla Şatıroğlu mahallesinden bir tanıdığın arsası satın alındı. Diğerleri devletin merasıydı. Çok vaatler verdiler hiç birine yardımcı olmadılar” (K1).

"Tarlaya dikilen direk yerleri istimlak edildi. Direklerin olduğu tarlalardaki ürünlerin fiyatını da ödediler. Direkler Kurugöl' den 30 kişsinin arazisinden geçti. Ödenen fiyat açısından memnundular. 
30 kişiden sadece 2 kişi itiraz etti ama sonra vazgeçtiler. Parseli ortak miras olan vardı onu mahkeme kararıyla aldılar. Bu işi de devlet yani Meram Elektrik Dağıtım A.Ş (MEDAŞ) yaptı” (K6).

Ankette yer alan "Rüzgâr santrali için yapılan kiralama ve kamulaştırmalar yerel halkın beklentilerini karşılamaktadır." şeklindeki soruya katılımcılar toplamda $\% 45,4$ oranında negatif görüş bildirmişlerdir.

Kamulaştırma, satın alma ya da kiralama yoluyla doğrudan oluşan ekonomik faaliyetler yanında özellikle rüzgâr enerji tesislerinin çevresel etkileri başlığında tartışılan "arazi parçalanması” konusuna Geycek santrali çevresinde de rastlanmıştır. Bu durum arazinin kullanım ve estetik değeri gibi tartışmaların beraberinde parçalanma ile ekonomik değerinin azalmasına da yol açmaktadır. $\mathrm{Bu}$ kapsamda Firestone ve Kempton (2007:1597) yerel topluluklarla yapılan araştırmalarda estetik ve mülk değerleriyle ilgili kaygıların çevresel kaygılardan daha yüksek olduğunu belirtmektedir.

"Bazı yerlerde istimlak edilen yerler araziyi ikiye böldügüüden karşıya geçişler zorlaştı ya da terk edildi. 10 dönümün 1'i öbür tarafinda kaldı dolanması gerektiğinden araziyi terk etti” (K2).

Kategori 3: Proje, İnşaat ve Işsletim Aşamasında Bölge İnsanından Sağlanan İşgücü

Rüzgâr enerji tesislerinin tüm dünyada rapor edilen en önemli ekonomik faydası yerel topluluklar için istihdam yaratması olduğu söylenebilir. Bununla birlikte tesislerin proje aşamasından işletim sürecine kadar olan farklı dönemlerinde yerel işgücü talebi değişkenlik göstermektedir.

Rüzgâr enerji tesislerinin inşaat aşaması en yüksek istihdamın yaratıldığı dönem olmaktadır. Holburn (2015), çalışmasında rüzgâr santrallerinin inşaat aşaması boyunca ortalama olarak 12 ay boyunca vasıfsız işçi gruplarının çalıştığını belirtmektedir. Çalışmasında, Kanada'nın Haldimand bölgesindeki rüzgâr santralinde, inşaat aşamasında 478 kişi tam zamanlı 1 yıl çalıştığını ifade etmektedir. Leistritz ve Coon (2009), Amerika'nın kuzey Dakota eyaletindeki rüzgâr santrali projesi için ekonomik etkilerini incelemiştir. İnceleme sonucu, yaklaşı 7-8 ay süren inşaat süresince toplamda 269 işçi çalışmıştır. Benzer biçimde Reategui ve Hendrickson (2011), Teksas da 1.000 MW'lık rüzgâr santralinde yaptıkları çalışmada inşaat iş̧̧ilerinin \%70-80'nin bölge halkından olduğunu ifade etmektedir. Yapılan görüşmelerle Geycek rüzgâr santralinin inşaat aşamasında yarattığı istihdam etkisinin literatürdeki bulgularla uyumluluk taşıdığı görülmüştür. Ulaşılan bilgilere göre inşaat döneminde istihdam sayısı maksimum 350 kişi olarak gerçekleşmiştir. İş kalemleri düşünüldüğünde bu dönem işlerinin genelde teknik bilginin istenmediği vasıfsız işlerden meydana geldiği görülmüştür.

"Şantiye döneminde dönemlik işçi çalıştı. İnşaat aşamasında 350 kişi 1 yıl boyunca çalıştı. Girdi-çıktılarla toplamda 1000 kişi istihdam edildi. Şirket prensibi olarak maksimum kişi çalıştırarak bölgedeki insanlarda kazansın istiyoruz"(K7).

"İņaatta bizim köyde 6-7 kişi çalıştı. Direk diktiler ve beton attılar. Tel çekim işinde çalıştılar. Asgari ücret artı sigorta yaptılar. Yemek parası 350-400 lira verdiler. 1 yıldan daha az vakit çalıştılar" (K4).

Ankette yer alan "Siz, bir yakınınız ya da tanıdığınız rüzgâr santralinin inşaat aşamasında gelir getiren bir işte çalıştı mı?" sorusuna katılımcılar \%49,5 oranında "evet" \%50,5 oranında ise "hayır" 
cevabını vermiştir. Ayrıca "Rüzgâr enerjisi bölge insanına iş olanağı yaratmaktadır." sorusuna da $\% 67,1$ ' lik oranla negatif skorları vermişlerdir.

Santrallerin inşaat aşamasında en yüksek düzeye çıkan istihdam oranı santrallerin işletme aşamasında görülmemektedir. Holburn (2015), Kanada'nın Haldimand bölgesindeki 443 MW güce sahip rüzgâr santralinde işletme döneminde ise 41 tam zamanlı çalışan olduğunu belirtmektedir. Otomasyon sistemleri bu dönemde özellikle, santrallerin düzenli çalışması için gerekli işlemlerin mesafe tanımadan yürütülmesine olanak sağlamaktadır. Bunun dışında şalt sahasındaki teknik birimler ve türbinlerin bakım onarını gerçekleştirecek ekipler kurucu firmanın bölge dışından getirdiği elemanlardan oluşturulmaktadır. Bunu belirleyen önemli faktörlerden biri genel anlamda bölgenin teknik birikimi daha dar anlamda ise rüzgâr enerji sistemlerine dönük bilgi birikimine sahip yetişmiş personelin bölgede bulunmamasıdır.

"Şu anda 20 kişi anca çalışıyor. Genellikle güvenlik ve şoför olarak çalışıyorlar. Maaşlar asgari ücret seviyesinde. Memnun değiller ama mecbur oldukları için çalışıyorlar” (K1).

"Budak köyünden 2 kişi çalışlyor. Biri tekniker diğeri de güvenlik olarak çalışıyor. Güvenlik asgari ücret allyor. Ama teknisyeni bilmiyorum. İşsizlikten çalışlyorlar. Para tatmin etmiyor mecburen çalışıyorlar” (K2).

Yapılan görüşmelerde santral yakını köylerde yaşayan sadece bir yüksekokul mezunu kişinin tekniker olarak santralde çalıştığı belirlenmiştir. Toplamda ise santral yetkilisinden alınan bilgiye göre yerel halk ve civar köylerden ağırlıklı olarak güvenlik görevlisi ve bunun dışında şoför, temizlik elemanı ve mutfak işlerine bakan 40 personelin istihdam edildiği öğrenilmiştir. Buna karşın söz konusu sayının fazla tutulmasının bölgeyi desteklemek amacıyla firma politikası olduğu belirtilmiştir.

"Biz tabi normalde bu kadar kişi çalıştırmayabilirdik. Güvenlik olarak silahlı ve yanlarında koruma amaçlı köpek bulundurarak 6 kişi yeterli olurdu. Fakat biz şirket politikası olarak bölge halkından maksimum kişi çalıştırma politikası uygulama amacındayız" (K8).

MW olarak rüzgâr santrallerinin büyümesi ile istihdam arasındaki doğru orantı sadece inşaat aşamasında görülmektedir. Bunun dişında tesisin büyük ya da küçük olması işletme aşamasında istihdam edilen işgücü anlamında değişiklik yaratsa da bu önemli miktarda gerçekleşmemektedir. İnşaat aşamasında 350 kişinin istihdam edilmesi bölgenin nüfusu ve ekonomik yapısı düşünüldüğünde dönemlikte olsa ekonomik etkileri açısında önemli bulunmaktadır. Buna karşın tesisin genel iş yaratma potansiyeli, bu yönüyle çevresini etkileme düzeyi ve bölge insanı tarafından bu etkilerin algılanması kısıtlı gerçekleşmektedir.

“ İnşaat aşamasında bizim köyden 6-7 civarında kişi çalıştı. İnşaat süresince çalıştılar. Şuan da (işletim) 1 kişi çalışıyor. Önceden 2 kişi çalışıyordu” (K4).

Kategori 4: Bölgede Süregelen Mevcut Ekonomik Faaliyetler, Değerler ve Santral Faaliyetinin Etkileşimi Sonucu Oluşan Ekonomik Durum

Geycek rüzgâr santrali çevresinde gözlemlenen son etki kümesi ise bölgede yürütülen ekonomik faaliyetlerle bütün halde santral faaliyetlerinin etkileşimiyle ortaya çıkan durumdur. ABD Ulusal Yenilenebilir Enerji Laboratuvarı (NREL, 2009) rüzgâr enerji sahalarında inşaat aşamasında MW başına 
3,5 dönüm, işletme aşamasında ise kalıcı 1 dönümlük rahatsızlık ortaya çıktığını rapor etmektedir. Peker (2001) tesislerin bir bölgede yerleşmesiyle o bölgede süregelen arazi kullanım ilişkilerinin değiştiğini, Pasqualetti (2002) ise doğal çevreden enerji çevresine dönüşümün gerçekleştiğini belirtmektedir.

Çalışma sahası daha önce belirtildiği üzere kırsal yerleşimlerin bulunduğu ve ağırlıklı olarak tarım ve hayvancılıkla uğraşılan bir bölgedir. Rüzgâr enerji sahalarının tarım ve hayvancılığa etkisini inceleyen çalışmaların seyrek, olanların ise değişken sonuçlar gösterdiği bilinmektedir. Tarımsal üretimle ilgili en büyük tartışma arazi parçalanması ve rüzgâr türbinlerinin sıcaklık değişimlerine yol açması nedeniyle tarımsal üretimde meydana gelen azalmadır.

"Tarlaların verimini öldürüyor. Ekilen ürünleri kuruttuğu için ekin alamıyoruz. Buğday ve Arpaya etkisi oldu. Santral hayvanları strese sokuyor. Insanlarda baş ağrısı yaptı̆̆ için hayvanlarda da baş ağrısı oluyor bu yüzden süt verimi düşüyor"'(K1).

Zhou vd. (2012) meteorolojik veriler ışığında kanatların oluşturduğu türbülansın önemli ölçüde yüzeye yakın havayı etkilediğini göstermektedir. Hayvancılığa bakıldığında Helldin vd. (2012) hazırladıkları raporda yollar, trafik, otlanma alanlarında oluşan kısıtlar ve gürültü gibi nedenlerle karasal memelilerin olumsuz etkilendiğini raporlamaktadır. Mikołajczak vd. (2013) kazlar üzerinde yaptıkları çalışmada türbinlere 50 metre yakınlıkta yer alan kümeste yaşayan kazların 500 metre uzaklıktaki kazlara göre daha az kilo aldığı ve stres hormonu kortizolun fazla olduğu saptanmıştır.

Ulusal Rüzgâr Koordinasyon Komitesi (NWCC, 2010) ise türler için çevresel bozulmaların asıl tehlike olduğunu rüzgâr enerjisinin tehlike yaratmadığı belirtilmektedir.

"Halkımız kulaktan dolma laflarla ekine zarar verdiğini söylüyorlar. Kuraklık var kar yağmur yok ama bu rüzgârla alakalı değil. Santralin hemen dışında da kuraklık var. Küçükbaş hayvanlar gezebiliyor. Büyükbaş zaten tepeye çıkmıyor geçiş amaçlı kullanıllyor. Hayvancıllğa zararıda yok karışanda yok" (K3).

"Tarım ve hayvancllı̆̆a bir etkisi olmadı. Hayvancılık devam ediyor. Tarım için de olumsuz bir durum söz konusu değil." (K5).

Yapılan görüşme ve anketlerde rüzgâr enerjisinin tarım hayvancılığa etkisi alg1 düzeyinde irdelenmiştir. Bu yönüyle görüşlerin kişisel deneyimler yanında medya ya da sosyal çevre nedeniyle ortaya çıkma olasılığı bulunmaktadır. Bu kapsamda ankette yer alan "Rüzgâr santrali Mucur'da tarım ve hayvanc1lık yapılan arazileri sinılandırmaktadır." sorusuna katılımcılar toplamda \%79,5 oranında kesinlikle katılmadığını belirtmiştir. Verilerinden alınan bu sonuç genel eğilimin rüzgâr enerjisinin tarım ve hayvancılığı olumsuz bir etkisi olmadığı üzerinedir. Görüşmecilerin genel yaklaşımı da anket sonuçlarıyla örtüşmektedir. Katılımcılardan sadece 1' i dışında tarım hayvancılık üzerine olumsuz görüş bildirmemiştir.

Taşınmaz malların değerinin rüzgâr enerji tesislerinden olumsuz etkileneceği görüşü diğer önemli ekonomik tartışmalardan biridir. Türbinler, enerji nakil hatları ya da şalt sahalarına yakın konut ve arazi fiyatlarının bu yapılaşmadan nasıl etkilendiğine dair çalışmalar bölge özelliklerine göre farklı sonuçlara ulaşabilmektedir. Hoen vd. (2011)'nin dokuz farklı ABD eyaletinde 24 rüzgâr tesisinin 10 mil yakınında bulunan yaklaşık 7.500 müstakil ev satışı hakkında veriye dayandırdığı çalışmada konut satış 
fiyatları üzerinde az sayıda evin olumsuz etkilenmiş olduğu olasılığını atlamadan tutarlı, ölçülebilir ve istatistiksel olarak anlamlı bir etki bulamamıştır. Buna karşın Sunak ve Madlener'in (2016) Kuzey RenVestfalya Federal Eyaletindeki çeşitli rüzgâr sahaları çevresinde bulunan mülklerin değerleri üzerindeki potansiyel devalüasyonunu araştırdığı çalışmada peyzaj ve manzaranın yoğun bir değişikliğe uğradığı konutlarda fiyatların yaklaşık \%10-17 oranında azaldığı bulunmuştur. Mulvaney vd. (2013) ise kısa zaman aralığında santralin ortaya çıkardığı değer değişiklikleri kestirebilmenin mümkün olmadığını bir düşüş ve artışı görebilmek için orta ve uzun vadede gözlemler yapılması gerektiğini belirtmektedir.

Geycek çevresinde ilgili kamu görevlilerinden alınan bilgi ve yapılan gözlemler doğrultusunda genelde taşınmaz değerlerinin yüksek olmadığı görülmektedir. Arsa fiyatlarında yaşanan artış ya da azalış ise rüzgâr santralinden bağımsız olarak büyük kentlerden tarım için gelenlerin talepleri, kuraklık ya da ürün verimliliği gibi nedenlerden kaynaklanmaktadır. Ankette yer alan "Rüzgâr santralleri sahip olunan taşınmazların değerini düşürmektedir.” sorusuna \% 63,6 oranla bölge insanı kesinlikle katılmamaktadır. Görüşme sorularına verilen cevaplarda bu durumu destekler niteliktedir.

"Arsalar zaten meraydı devletten aldılar. O yüzden arsa fiyatları artmadı. Ama milletin çoğu büyü̈şsehirden geri geliyor. Büyükşehirden geri dönüş var. Arsa fiyatları ondan arttı santralle bir alakasl yok" (K4).

\section{Kategori 5:Ekonomik Etkiler ve Sosyal Kabul}

Rüzgâr enerjisinin ekonomik faydaları ve sosyal kabul arasında sıkıntılı bir sınır bulunmaktadır (Aitken, 2010).Tüm rahatsızlıklara rağmen özellikle doğrudan elde edilen faydaların rahatsızlıkları gizleyen/öteleyen bir rüşvet görevi görebileceği belirtilmektedir. K1 ile kodlanan görüşmecinin yorumu bu açıdan önemlidir. Görüşmeci köyün güzelliği, meraların işgali ile ilgili rahatsızlığını belirtirken gelebilecek faydalarla tesislere kapıyı aralayabilmektedir.

"Köyün güzelliğini bozdular hayvancıllğı etkilediler. Beklentimiz, köylerimize hizmetlerin daha iyi olabilmesi iken, aksine meralar işgal edildi. Bana faydası olmayan kilise papazını ben napayım. Yerele hiçbir zaman faydası olmayan bir malzemenin bizim evde işi yoktur” (K1).

Bununla birlikte Mucur Rüzgâr Santralinin planlama noktasında yerleşimler, sürdürülen faaliyetler ile kısıtlı etkileşim, tesisin Armutlu (1554m.)dağ sırtı boyunca uzanan yapısı nedeniyle söz konusu rahatsızlıkların yüksek düzeyde olmadığı, hatta bazı insanlar için gündem oluşturmadığı gözlemlenmektedir. Ayrıca tesisin yerleştiği arazinin bitki örtüsü açısından3.sınıf arazi statüsünde yer alması estetik veya manzara bozulması tartışmalarını ağırlıklı gündem olmaktan çıkarmaktadır.

"Rüzgâr enerjisine karşı herhangi bir fikrim yok olsa da olur olmasa da ama ĕger ekonomik faydası olacaksa kurulabilir”(K6).

"Görüntü anlamında daha güzel oldu. Gün batımını izlemenizi tavsiye ederim Ekonomik fayda sağlayan, insanların para kazandı̆̆ işlere olumlu bakarım”(K4).

Yukarıda gruplanmış ekonomik etkiler dışında özellikle Almanya, Danimarka ülke örneklerinde gözlemlenen topluluğun, yerel kooperatiflerin sahipliğinde tesisler ve yerele doğrudan finansal katkı sunan modeller Türkiye'de bulunmamaktadır. Geleneksel rüzgâr enerjisi projelerine kıyasla, topluluk denetimli/sahipliğinde gelişen rüzgâr projeleri ekonomik faydalar açısından daha büyük etkiye sahiptir 
(NREL, 2009). Lantz ve Tegen (2009) bu modelle geliştirilen projelerin inşaat dönemi istihdam etkilerinin geleneksel modele göre 1,1 ila 1,3 kat daha yüksek ve işletme döneminde ise 1,1 ila 2,8 kat daha yüksek olduğunu belirtmektedir.

Tüm bunlara rağmen Mucur ilçesinde rüzgâr enerjisine yönelik genel destek ve hoşnutsuzluk dengesi dünya örnekleriyle örtüşmektedir. Örneğin Mulvaney (2013) ABD'de Benton County şehrindeki çalışmasında, rüzgar enerjisine karşı sınırlı bir muhalefet olmasına rağmen, bu enerji türünün sağladığı ekonomik faydaların halkın büyük çoğunluğunun olumlu bir algıya sahip olmasına katkı sağladığını belirtmektedir. Warren ve McFadyen'in (2010) ise Güney-Batı İskoçya'da Kintyre Yarımadası ile Gigha Adası'nda karşılaştırmalı olarak yaptıkları çalışmada ticari şirketlerin sahip olduğu sahaların yer aldığg Kintre'ye nazaran topluluk üyelerinin mülkiyetindeki sahanın yer aldığ1 Gigha'da rüzgâr enerji sistemlerine dönük daha olumlu tutum ve davranışın geliştiği görülmüştür. Ankette yer alan "Mucur da rüzgâr santrali kurulmasını doğru buluyor musunuz?" sorusuna katılımcıların \% 81,2'lik oranı olumlu bakmaktadır. Ayrıca rüzgâr enerjisinin ülkelerin enerji güvenliği gibi konularda sağladığı avantajlara dönük farkındalık anket ve görüşme katılımcıları arasında gözlemlenmektedir.

"Bize bir zararı yok ekonomiye faydası var dışa bağımlılı̆̆ı azaltıyor. Ekonomik güç olarak önemli. Daha önce yapılsaydı daha iyi olurdu. Güneşe ve rüzgâra yatırım yapmamız lazım” (K3).

İlçenin yukarıda değinilen sınırlı ekonomik faaliyetlere ev sahipliği etmesi, insanların gelir düzeyinin düşük olması sistematik bir ekonomik girdinin kolayca etkilerinin hissedilebileceği bir ortam sunmaktadır. Bununla birlikte tesisin ekonomik etkileri yukarıda başlıklar halinde verildiği üzere sınırlı ve dağınık bir özellik göstermektedir. Bu yönüyle bölgedeki ekonomiyi canlandıracak, bir gelir artışına yol açacak potansiyeli taşımamaktadır. Tesisin kabul süreçlerinde ekonomik faydalardan ziyade yerleşimlerle düşük düzeyde gerçekleşen etkileşimin ve rüzgâr enerjisine dönük genel olumlu bilginin daha etkili olduğu gözlemlenmektedir. Bununla birlikte bir plan dâhilinde uygulanacak ekonomik programların yerel halkın ilgisini arttıracağı, kabul süreçlerini pekiştireceği düşünülmektedir.

\section{Sonuç}

Sonuç olarak mevcut araştırma ile Geycek rüzgâr santrali civarında yaşayan yerel halkın toplumsal algı düzeyinin derecesi ölçülmeye çalışılmıştır. Yapılan araştırmada dünya içerisinde çeşitli örnekleri olmasına rağmen mevcut ekonomik faydaları dört ana başlık altında toplanmıştır. Yapılan bu araştırma barındırdığı konu ile bağlantılı olarak daha detaylı araştırmaları doğurabilir. Örneğin, mevcut araştırmadan farklı olarak santralin kurulduğu tarihten itibaren mikro ve makro ekonomik etkileri analiz etmek (emlak değerleri, GSMH vb.) ufuk açıcı olabileceği düşünülmektedir. Bu tarz etki analiz araçları kullanılarak yapılacak olan bir araştırma, sistemli hali getirilirse zaten büyük oranda olumlu olarak algılanan ekonomik etkiler daha da pekiştirilebilir. Ayrıca, ileride yapılacak olan rüzgâr enerjisi yatırımlarında, teknik bilgi ihtiyacının ve çeşitli sanayi kollarına ait teknik iş ve malzemelerinin yerelden karşılanma potansiyeli arttıkça mevcut ekonomik etkiler daha da artacağı düşünülmektedir.

Geycek rüzgâr enerjisi sağladığı ekonomik faydalar ve harekete geçirdiği sektörler nedeniyle yerel kalkınma araçlarından biri olarak görülen rüzgâr enerji tesislerinin araştırma yaptığımız saha için 
etkilerinin sınırlı düzeyde kaldığı söylenebilir. Bunda bölgenin teknolojik taşıma kapasitesinden yetkin insana vb. birçok neden bulunabilir. Ekonomik etkinin genişletebilmesi için bölgede veya Kırşehir ilinde bulunan yüksekokul veya teknik liselerde, rüzgâr enerjisi teknolojisi ile alakalı çeşitli bölümler kurularak kalifiye insanların yetişmesi sağlanabilir. Çünkü mevut durumda Geycek rüzgâr santralinden sorumlu şirket teknik eleman ihtiyacını bölge dışından sağlamaktadır. Bunun dışında rüzgâr santralinin bakım/oranım veya parça temini gibi ihtiyaçları yine bölge dışından sağlanmaktadır. Bölgede rüzgâr enerjisi teknolojisinin beslediği diğer sektörlere yönelik yapılacak yatırımlarla tesisin ihtiyaç duyduğu bakım hizmetlerini sağlayabilme olanağı ortaya çıkacaktır. Ayrıca Mucur ilçesinin İç Anadolu bölgesinde kavşak bir bölgede yer alması, diğer bölgelere olası ihracatında önüne açılabilecektir.

Rüzgâr enerjisi, kurulduğu bölgede çeşitli sanayi kollarını geliştirme potansiyeli yüksek iken Mucur ilçesi ve yakın çevresinde rüzgâr enerjisi teknolojilerine yönelik teknik bilgi potansiyeli olan kişi sayısı sınırlı olduğu olmasından dolayı sektörel bazlı bir gelişim olmamıştır. Fakat yine de bölgeye en sistemli katkı inşaat aşamasında, kaba işlerde(beton atma, tel çekimi, inşaat işleri vb.) ve sonrasında güvenlik, şoför ve aşçı gibi teknik olmayan işlerde hissedilmiştir. Bunlar gereklilikten değil şirket tarafından uygulanan bir sosyal proje olarak ortaya çıkmaktadır. Çünkü santral yetkililerinden alınan bilgilere göre teknik olmayan işlerde çalışllacak kişiler bilinçli olarak santralin civarındaki köylerden seçilmiştir.

Halkın sosyal kabul derecesi düşünüldüğünde, yapılan görüşmeler ve anket sonucu genel itibariyle Geycek rüzgâr santraline karşı büyük oranda olumlu bir görüş hâkimdir. Tarım ve hayvancılığın başat ekonomik faaliyet olarak yürütüldüğü bir bölgede rüzgâr enerjisinin sınırlı da olsa istihdam, satın alma vb. gibi araçlar sayesinde dönemsel ve sürekli ekonomik etki yaratması halk tarafından rüzgâr enerjisine karşı ilgiyi artırmıştır. Fakat örneklem içerisinde yer alan bazı kişiler mevcut faydaları yetersiz görmekte ve muhalif/eleştirel bir tavır sergilemektedir. 


\begin{tabular}{ccc} 
Coğrafi Bilimler Dergisi & Cografi \\
Bilimler & Dergisi \\
\hline
\end{tabular}

\title{
Economic Effects of Wind Energy Systems and Social Acceptance: Mucur Case
}

\author{
Z. Emir Taşkın*a, MutluYılmaz ${ }^{\mathrm{b}}$, Çağdaş Kılıçc
}

\section{EXTENDED ABSTRACT}

\section{Introduction}

The amount of energy consumption has been constantly increasing, due to the increase in world population and industrialization. Therefore, states give importance to energy policies to provide necessary energy. In this context, fossil-based energy sources have gained importance thanks to their low cost and accessibility. Moreover, the dominance of fossil-based energy sources is expected to continue in the following years (2017-2040) (EÜAŞ, 2020). However, the fact that fossil energy sources cause serious environmental problems and they will be exhausted lead the interest in renewable energy sources to increase (Y1lmaz, 2012:33). Also, Oil crisis in 1970's has increased the interest in renewable energy sources. During this time, wind power has been the most developed energy type and it has started to be used in 100 countries nowadays (Enerji Atlas1, 2019).

Wind power has been supported by public because it is a renewable energy source. However, the dispersed structure of wind power effecting different locations reveals different reactions other than general positive public opinion in the regions where they are installed. Thanks to increasing number of examples and experiences, it has been found out that wind power plants create socio-cultural, environmental, economic connection and relation with peripheral systems., and this situation has caused the emergence of "social acceptability" term. Social acceptability includes the effect of actions caused by the implementation of the project; the opinions, feeling and reactions of the public to this effect. The fact that the spread of wind energy systems affects landscape and lifestyles, so political, economic, and environmental stimuli cause oppositional behavior as well as support (Kılıç, et al., 2017: 152) constitutes the context of social acceptance. Despite significant numbers of studies in international literature, there are restricted number of studies that have been conducted on measuring the dynamics of social acceptability of wind power in Turkey. In light of all these, it is aimed to see how the economic effects cause by the wind power plant activity are evaluated by the people of the region through field work carried out around the Geycek wind farm in Mucur District of Kırşehir province and to measure their impact on attitudes towards Geycek wind farm.

\footnotetext{
* Corresponding Author: emir.taskinn06@mail.com

aAnkara University, Graduate School of Social Sciences Ankara/Turkey, https://orcid.org/0000-0002-0476-9891

${ }^{b}$ Ankara University, Faculty of Language, History and Geography, Geography Department, Ankara/Turkey, https://orcid.org/0000-0001-8914-1165

${ }^{c}$ Ankara University, Graduate School of Social Sciences Ankara/Turkey, https://orcid.org/0000-0002-0218-2907
} 


\section{Methodology}

In the study, a mixed method was used in which qualitative and quantitative research techniques were applied together. In determining the settlements where the sample will be selected, a maximum zone limit of 2500 meters was determined for Impact Analysis by taking Geycek wind farm to the center. Although this limit differs by Country, region, or study (Braunholtz, 2003; Brown et al., 2012; Swofford and Slattery, 2010; Warren et al., 2005) when the topographic characteristics of the study site were taken into account, the inclusion of the 2500-meter limit was found to be high. In this context, Gycek, Budak, Büyükburunağıl, Küçükburunağıl and Obruk villages were included in the study. Although the village of Kurugöl is not located within the established boundaries, it was included in the study due to the fact that the power transmission line passes through its land.

\section{Findings}

The findings of the study are attempted to be understood through the economic themes of wind energy facilities in the literature associated with social acceptance. In this context, it has been categorized under five headings.

Category 1: Economic Activities Created by the Staff Employed by the Founding Firms and subcontractors through Accommodation, Food and Beverage or Simple Leases in the District Center and Related Villages

When the literature on social acceptance processes of renewable energy systems is examined, it is stated that people working in the plant project and construction phase in rural area sand coming from outside the region boost the trade in these regions. Accommodation, food and beverage services, house and car rentals are shown as the activities which boost that dynamism in that particular region. The participants in the search field stated that the employees of the company that undertook the construction of the power plant met their various needs in Mucur district during the construction phase and the ongoing operation phase. However, it is understood that this benefit is far from the scale which increases the economic dynamism and mainly consists of commercial relations that generate small income at the personal level.

"It was useful, they made money and ate their food. They used the market and bought clothes and shoes, but that's not muchuseful, at all" (68. Survey 26/08/2018, Male)

\section{Category 2: Economic Activities Occurring Through Expropriation, Purchase or Leasing}

\section{Processes}

Another economic activity encountered in the study area is the transfer of the private registered land entering the route of the facility and energy transmission lines by leasing, purchasing or expropriation. Most of the lands in the region where the power plant is established are state-owned pasture areas. Therefore, the amount of land expropriated, purchased or leased due to the project was limited. However, purchasing activities were more intense in Kurugöl village, where ETL (Energy Transmission Line) passes through. The purchased lands do not have large plots. Due to the energy transmission line, the lands where the power poles pass through the fields have been expropriated. The general tendency of the interviewees is that the fields are bought or expropriated for a reasonable price. 
"They did not make us satisfied. As far as I know, the land of an acquaintance was bought from Şatıroğlu neighborhood. Others were state pastures. They gave so many promises but they didn't help any of them" (K1)

For the statement included in the survey, "The lease and expropriations made for the wind power plant meet the expectations of the local people", participants stated a negative opinion of $45.4 \%$ in total.

Category 3: The Labor Force Provided from The People of The Region During The Project, Construction And Operation Phase

It can be said that the most important economic benefit of wind power plants reported around the world is creating jobs for local communities. However, local labor demand varies in different periods from the project stage to the operation process. With the interviews, it was observed that the employment effect created by the Geycek wind power plant during the construction phase is in accordance with the findings in the literature. According to the information obtained, the number of employment during the construction period was 350 people. Considering the work items, it was seen that the jobs of this period consisted of unqualified jobs for which technical knowledge was not required.

"Seasonal workers worked in the construction site. During the construction phase, 350 people worked for one year. In total, 1000 people were employed within put-outputs. As a company principle, we want people in the region to win by employing maximum people. (K7)

For the question in the survey, "Did you or you acquaintance work in an income generating job during the construction phase of the wind farm?", $49.5 \%$ of the participants answered "yes" and 50.5\% of them said "no". Also, they gave negative scores with a rate of $67.1 \%$ to the statement in which it is asked whether wind energy creates job opportunities for the people of the region or not.

\section{Category 4: Economic Situation as a Result of the Interaction of Current Economic Activities, Values and Power Plant Operation in the Region}

The working area is a region with rural settlement sand mainly engaged in agriculture and animal husbandry. Studies examining the effects of wind energy fields on agriculture and animal husbandry have been sparse, and those studies are known to show variable results. The biggest debate about agricultural production is the reduction in agricultural production due to land fragmentation and wind turbines causing temperature changes.

"Our people say that they damage the crops with hearsay. There is drought, and no rain; but it has nothing to do with the wind. There is also a drought just outside the power plant. Ovine animals can roam. Bovine animals do not go up the hill anyway. They are used for transitional purposes. There is no harm to animal husbandry and no one is concerned about it"(K3).

In the interview sand surveys, the effect of wind energy on agricultural livestock was examined at the level of perception. In this respect, a small opinion may be formed due to the media or social environment as well as personal experiences. In this context, the participants stated that $79.5 \%$ of them strongly disagreed with the statement; "The wind power plant limits the agricultural and livestock lands 
in Mucur" in the questionnaire. This result from the data shows that the general opinion is that the wind energy does not have a negative effect on agriculture and animal husbandry.

\section{Category 5: Economic Impacts and Social Acceptance}

There is a troubling line between the economic benefits of wind energy and social acceptance (Aitken, 2010). Despite all the inconveniences, it is stated that especially the direct benefits can act as a bribery that repels the inconveniences. The comment of the interview coded as with $\mathrm{K} 1$ is important in this respect. While the interviewer stated the beauty of the village and his discomfort about the occupation of the pastures, he is open the facilities and with the benefits that may come.

"They spoiled the beauty of the village and affected animal husbandry. While our expectation was that services to our villages would be better, pastures were occupied. What can I do with the church priest who is of no use to me. A material that is never useful to the local has no place at home" (K1).

In the questionnaire, for the question "Would you approve of a wind farm to be built in Mucur ?" $81.2 \%$ of the participants answered positively. In addition, awareness of the advantages of wind energy to countries on issues such as energy security is observed among the participants of the survey and interview.

"It does no harm to us, it is beneficial for the economy, it reduces foreign dependency. It is important as an economic power. It would be better if it had been done before. We need to invest in the sun and wind" (K3).

\section{Conclusions}

It can be said that the economic benefits provided by the Geycek wind farm stayed limited for the field were searched. Many reasons can be found from the technological carrying capacity of the region to competent people, etc. While wind energy has a high potential to develop various industrial branches in the region where it is established, there has not been a sector-based development due to the limited number of people with technical knowledge potential in Mucur district and its surrounding areas. However, the most systematic contribution to the region was felt during the construction phase, rough works (concrete casting, wiredrawing, etc.) and later in non-technical workers such as safety guard, driver and cook.

Considering the degree of social acceptance of the public, the results of the interviews and surveys generally have a positive opinion towards the wind farm. Even though wind energy is limited in employment and offering purchasing ability in the region with rural economic characteristics, the periodic and continuous economic impact of such tools has increased the public's interest in wind energy. However, some people in the sample see the current benefits inadequate and stand on the opposite side.

\section{Referanslar/References}

Aitken, M. (2010). Why we still don't understand the social aspects of wind power: A critique of key assumptions within the literatüre. Energy Policy, 38, 1834 -1841. doi.org/10.1016/j.enpol.2009.11.060.

Altunışık, R., Coşkun, R., Bayraktaroğlu, S., Yıldırım, E. (2010). Sosyal Bilimlerde Araştırma Yöntemleri. Sakarya Yayıncılık. Arslan, F., Uzun, A. (2017). Yenilenebilir Enerji Yatırımlarının Sosyal Kabul Boyutu, Dumlupınar Üniversitesi Sosyal Bilimler Dergisi, 51 (1), 95-116. https://dergipark.org.tr/en/pub/dpusbe/issue/27739/294759 adresinden alınd1. 
Bauwens, T. (2015). The Effect of Cooperative Ownership on Social Acceptance of Onshore Wind Power: a Multi-Method Analysis, Centre For Social Economy, HEC Management School of the University of Liege, https://cidd2015.sciencesconf.org/51228/document adresinden alınd1.

Braunholtz, S. (2003). Public Attitudes to Wind farms: A Survey of Local Residents in Scotland. MORI Scotland.

Bristow, G., Cowell, R., Munday, M. (2012). Windfalls for whom? The evolving notion of 'community' in community benefit provisions from wind farms. Geoforum, 43 (6), 1108-1120. doi:10.1016/j.geoforum.2012.06.015.

Brown, J. P., Pender, J., Wiser, R., Lantz, E., Hoen, B. (2012). Ex post analysis of economic 1mpacts from wind power development in U.S. counties. Energy Economics, 34, 1743-1754. doi:10.1016/j.eneco.2012.07.010.

Cohen, M. R. (2010). A Clean Energy Economy for North Dakota: Analysis of the Rural Economic Development Potential of Renewable Resources. Natural Resources Defense Council.

Elektrik Üretim Anonim Şirketi (EÜAŞ, 2020). Elektrik Üretimi ve Ticareti Sektörü Raporu 2019, Strateji Geliştirme Dairesi Başkanlığı Stratejik Planlama Müdürlüğü. https://www.euas.gov.tr/tr-TR/sektor-raporu adresinden alındı.

Enerji Atlas1, (2019). Geycek Rüzgâr Santrali (RES). http://www.enerjiatlasi.com/ruzgar/geycek-ruzgarsantrali.html adresinden alınd.

Firestone, J., Kempton, W. (2007). Public opinion about large offshore wind power: Underlying factors. Energy Policy, 35 (3), 1584-1598. doi:10.1016/j.enpol.2006.04.010.

Graziano, M., Lecca, P., Musso, M. (2017). Historic paths and future expectations: the macro economic impacts of the offshore wind technologies in the UK. Energy Policy, 108 (C), 715-730. doi:10.1016/j.enpol.2017.06.042.

Greene, J. S., Geisken, M. (2013). Socio economic impacts of wind farm development: a case study of weather ford, Oklahoma, Energy, Sustainability and Society. 3 (1), 1-9. doi:10.1186/2192-0567-3-2.

Helldin,J. O., Jung, J., Neumann, W., Olsson, M., Skarin A., Widemo, F.. (2012). The Impacts of Wind Power on Terrestrial Mammals. Swedish Environmental, Protection Agency, Report No:6499. http://naturvardsverket.se/Documents/publikationer6400/978-91-620-6510-2.pdf adresinden alınd1.

Hoen, B.,Wiser, R., Cappers, P., Thayer, M., Sethi, G. (2011).Wind energy facilities and residential properties: The effect of proximity and view on sales prices. Journal of Real Estate Research, 33 (3), 279-316. https://econpapers.repec.org/article/jreissued/v_3a33_3an_3a3_3a2011_3ap_3a279-316.htm adresinden alınd1.

Holburn, G. (2015). The Local Economic Benefits of Wind Power Development and Operation, A Case Study of Haldimand County and Neighbouring Aboriginal Groups, Ontario, https://www.cordeliopower.com/wpcontent/uploads/2018/06/HaldRegion_EconBenefits-Feb2015.pdf adresinden alınd.

International Energy Agency, (IEA, 2019) Key World Energy Statistics. https://webstore.iea.org/key-world-energy-statistics2019 adresinden alınd1.

International Renewable Energy Agency, (IRENA, 2020). Renewable Capacity Statistics 2020. https://www.irena.org/publications/2020/Mar/Renewable-Capacity-Statistics-2020 adresinden alındı.

Kılıç, Ç., Yılmaz, M., Sarı, R. (2017). Rüzgâr enerji sistemlerinin sosyal kabul dinamiklerini anlamak. Coğrafi Bilimler Dergisi, 15 (2), 135-156. doi:10.2139/ssrn.3418354.

Lantz, E., Tegen, S. (2009). Economic Development Impacts of Community Wind Projects: A Review and Empirical Evaluation, Preprint, United States. https://www.osti.gov/servlets/purl/952188 adresinden alınd.

Lecca, P., McGregor, P. G., Swales, J. K., Tamba, M. (2017). The Importance of learning for achieving the UK's targets for offshore wind. Ecological Economics, 135 (C), 259-268. doi:10.1016/j.ecolecon.2017.01.021.

Leistritz, L. F., Coon, R. C. (2009). Socioeconomic impacts of developing wind energy in the Great Plains. Great Plains Research, 19, 3-12. https://www.jstor.org/stable/23779798?seq=1 adresinden alınd.

Meteoroloji Genel Müdürlüğü (MGM, 2020). İllere Ait Mevsim Normalleri (1981-2010) https://www.mgm.gov.tr/veridegerlendirme/il-ve-ilceler-istatistik.aspx? $m=$ KIRSEHIR adresinden alınd1.

Mikołajczak, J., Borowski, S., Marć-Pieńkowska, J., Odrowąż-Sypniewska, G., Bernacki, Z., Siódmiak, J., Szterk, P. (2013). Preliminary studies on the reaction of grow inggeese (Anseranser $\mathrm{f}$. domestica) totheproximity of windturbines. Polish Journal of Veterinary Sciences, 16 (4), 679-686. doi: 10.2478/pjvs-2013-0096.

Mucur Belediyesi (2020). Ekonomi. http://mucurbelediyesi.bel.tr/sayfa/ekonomi.html adresinden alındı.

Mulvaney, K. K., Woodson, P., Prokopy, L. S. (2013). Different shades of green: A case study of support for wind farms in 
the rural midwest. Envirion Manage, 51 (5), 1012-1024. doi:10.1007/s00267-013-0026-8.

Munday, M., Bristow, G., Cowell, R. (2011).Wind farms in rural areas: How far do community benefits from wind farms represent a local economic development opportunity. Journal of Rural Studies, 27 (1), 1-12. doi:10.1016/j.rurstud.2010.08.003.

National Wind Coordinating Collaborative (NWCC, 2010). Wind Turbine Interactions with Birds, Bats, and their Habitats: A Summary of Research Results and Priority Questions. National Wind Coordinating Collaborative, Washington, DC. https://www1.eere.energy.gov/wind/pdfs/birds_and_bats_fact_sheet.pdf adresinden alınd1.

Okkonen, L., Lehtonen, O. (2016). Socio-economic impacts of community wind power projects in Northern Scotland. Renewable Energy, 85, 826-833. doi:10.1016/j.renene.2015.07.047.

Osterberg, D., Distler, E. (2003). Wind power and lowa economy. Lowa Research Online, (10:1), 1-17. www.iowapublicyproject.org adresinden alınmıştır.

Palabıyık, H., Yavaş, H., Aydın, M. (2010). Türkiye'de nükleer santral kurulabilir mi? Çatışmadan uzlaşıya: Türkiye'de nükleer enerji projelerinde sosyal kabul sorunu ve halkın reddetme sendromunun araştırılması. Girişimcilik ve Kalkınma Dergisi, 5 (2), 176-201. http://acikerisim.lib.comu.edu.tr:8080/xmlui/handle/COMU/349 adresinden alınd1.

Pasqualetti, M. J. (2002). Living with wind power in a hostile landscape. Wind power in view. Energy land scapes in a crowded World içinde (153-172). San Diego: Academic Press.

Peker, Z. (2001). Rüzgâr enerjisinin çevresel etkileri ve bu etkilerin azalmasında planlamanın rolü. Mühendis ve Makine, 43 (509), 36-40.

Peker, Z. (2012). Yenilenebilir enerji girişimlerinin sosyal boyutu, Dokuz Eylül Üniversitesi Sosyal Bilimler Enstitüsü Dergisi, 15 (4), 663-691. https://acikerisim.deu.edu.tr/xmlui/handle/20.500.12397/5304 adresinden alınd1.

Reategui, S., Hendrickson, S. (2011). Economic Development Impact of 1000 MW of Wind Energy in Texas, Technical Report NREL/TP-6A20-50400, National Renewable Energy Laboratory. doi: 10.2172/1022293.

Slattery, C. M., Lantz, E., Johnson, B. L. (2011). State ve local economic impacts from wind energy projects: Texas case study. Energy Policy, 39 (2011), 7930-7940. doi:10/1016/j.enpol.2011.09.047.

Sunak, Y.,Madlener, R. (2016). The impact of wind farm visibility on property values: A spatial difference-in-differences analysis, Energy Economics, 55 (C), 79-91. doi:10.1016/j.eneco.2015.12.025

Swofford, J., Slattery, M. (2010). Public attitudes of wind energy in Texas: Local communities in close proximity to wind farms and their effect on decision-making. Energy Policy, 38 (5), 2508-2519. doi:10.1016/j.enpol.2009.12.046.

Şenel, M. C., Koç, E. (2015).Dünyada ve Türkiye'de rüzgar enerjisi genel durumu-genel değerlendirme. Mühendis ve Makina, 56 (663), 46-56. https://dergipark.org.tr/en/pub/muhendismakina/issue/54195/733672 adresinden alınd1.

Toke D., Breukers, S., Wolsink, M. (2008). Wind power deployment outcomes: How can we account for the differences? Renawable and Sustainable Energy Reviews, 12 (4), 1129-1147. doi:10.1016/j.rser.2006.10.021.

TÜIKK. (2020). Adrese Dayalı Nüfus Kayıt Sistemi Sonuçları. https://biruni.tuik.gov.tr/medas/?kn=95\&locale=tr_adresinden alındi.

Türkiye Rüzgâr Enerjisi Birliği (TUREB, 2020). Türkiye Rüzgâr Enerjisi İstatistik Raporu. https://www.tureb.com.tr/bilgibankasi/turkiye-res-durumu adresinden alınd1.

Uzun, A., Arslan, F. (2018). Termik santral projelerinin sosyal kabul boyutu: Paşaköy (Balıkesir) termik santrali örneği. Balıkesir Üniversitesi Sosyal Bilimler Enstitüsü Dergisi, 21 (40), 27-52. doi:10.31795/baunsobed.489087.

Warren, C. R., Lumsden, C., O’Dowd, S., Birnie, R.V. (2005). Green on Green': Public perceptions of wind power in Scotland and Ireland. Journal of Environmental Planning and Management, 48 (6), 853-875. doi:10.1080/09640560500294376.

Warren, C. R., McFadyen, M. (2010). Does community ownership affect public attitudes to wind energy? A case study from south-west Scotland. Land Use Policy, 27 (2), 204-213. doi:1016/j.landusepol.2008.12.010.

Yılmaz, M. (2012).Türkiye'nin enerji potansiyeli ve yenilenebilir enerji kaynaklarının elektrik enerjisi açısından önemi. Ankara Üniversitesi Çevre Bilimleri Dergisi, 4 (2), 33-54. doi:10.1501/Csaum.0000000064.

Zhou L., Tian Y, BaidyaRoy, S., Thorncroft, C., Lance, F. B., Hu, Y. (2012). Impacts of wind farms on land surface temperature. Nature Climate Change, 2, 539-543. doi:10.1038/nclimate1505. 